\title{
Thinking Differently about 'False Allegations' in Cases of Rape: The Search for Truth
}

\author{
Jacqueline M. Wheatcroft ${ }^{1, *}$ and Sandra Walklate ${ }^{2}$ \\ ${ }^{1}$ Department of Psychological Sciences; ${ }^{2}$ Department of Sociology, Social Policy \& Criminology, University of \\ Liverpool, Liverpool, UK
}

\begin{abstract}
The myth 'cry wolf' continues to pose particular problems for campaigners, policy makers and practitioners. This paper subjects this myth, and the way in which it has been debated, to critical scrutiny with a view to suggesting an alternative and better way of challenging the presumption both in theory and in practice that women 'cry wolf'. In reflecting on lessons learned that presume believability in establishing rapport from the treatment of children in sexual offence cases the paper suggests that such practices can maximise efficacy in the treatment of women in cases of rape. It concludes that by leaving accusatory language behind, complainants, practitioners and judicial parties may experience more successful pathways to truth.
\end{abstract}

Keywords: False Allegation, Rape, Truth, Interactional Belief.

\section{INTRODUCTION}

The events surrounding Dominique Strauss-Kahn in May 2011 brought back into the public domain a range of questions pertaining to the success or otherwise of allegations of rape and/or sexual assault. Unfortunately, those events gave new meaning to the question asked by Belknap (2010:1341) "Can a victim ever charge a powerful, wealthy, and/or celebrity male with rape without being seen as a "gold-digger" or/and a "liar"'. It offered a timely reminder of the continued 'importance of being perfect' (Adler 1987) on the part of the rape complainant, whether inside or outside of the witness box, along with the persistent power of the myths that surround cases of rape and/or sexual assault (the sex of the complainant notwithstanding). This paper focuses on one feature of those myths that continues to pose particular problems for campaigners, policy makers and practitioners: the belief that women 'cry wolf'.

The view expressed by Sir Matthew Hale in 1680 that rape 'is an accusation easily to be made and hard to be proved, and harder to be defended by the party accused, tho' never so innocent' (quoted by Gavey and Gow 2001:343) reflects a deeply held historical and contemporary resonant view that women (and children) lie. This view, endorsed in Greek mythology and religious texts such as the Bible, implies that women engage in claiming rape as an act of revenge, fantasy, or deceit to hide her own sexual appetite or deviancy. Indeed the presumed female capacity for deceit

*Address correspondence to this author at the Institute of Psychology, Health \& Society, Department of Psychological Sciences, Witness Research Group, University of Liverpool, Eleanor Rathbone Building. Bedford Street South, Liverpool L69 7ZA, UK; Tel: +44 (0)1517950513; Fax: +44 (0)1517946937; E-mail: jacmw@liv.ac.uk, S.L.Walklate@liverpool.ac.uk underpins a number of the myths that surround rape. Myths, that as Brown and Horvath (2009:332) point out, '....become part of a self-supporting system whereby the absence of convictions supports the belief that women falsify claims or men's behaviour does not justify the charge', as in the media coverage of the case of Dominique Strauss-Kahn with which this paper began.

The fear of false allegation in cases of rape has informed legal doctrine in a number of ways from the corroboration warning to the historical immunity given to 'marital rape' (Rumney 2006). There is also evidence to suggest that this fear has informed and continues to inform policing and prosecution decisions (see inter alia Brownmiller 1975; Jordan 2008; Stanko and Williams 2009) and awareness of the likelihood of being accused of lying impacts upon complainants' willingness to report (Stern 2010). Indeed media coverage of false allegations (and here the StraussKahn case is no exception) has served to fuel debates in the U.K. and elsewhere that defendants should be given the same right to anonymity as complainants (Ministry of Justice 2010; Gavey and Gow 2001). It is worth noting that such debates have been generated on the flimsiest (if any) evidence (Ministry of Justice 2010). All of which illustrates the considerable ideological sensitivities that continue to exist on the veracity of women. Moreover, and perhaps more importantly, over the last twenty years a good deal of criminal justice resource in a wide range of jurisdictions has been devoted to improving responses to sexual assault. Yet it would seem that the intractable problem of beliefs around women (and children) 'crying wolf' remains. Furthermore, there is evidence to suggest that this takes a particular toll on vulnerable complainants 
who may be the least able to deal with what has happened to them (Stanko and Williams 2009). So the question that Kelly (2010:1346) asks; 'Why does the spectre of false allegations cast a sceptical shadow over the words of every woman and child?' remains pertinent.

The purpose of this paper then is to subject this particular myth, and the way in which it has been debated, to critical scrutiny with a view to suggesting an alternative, and hopefully better, way of challenging the presumption both in theory and in practice that women (and children) 'cry wolf'. In order to do this, the paper falls into three parts. In the first part we shall consider some of the problems associated with understanding and defining what counts as a 'false allegation' in cases of rape and sexual assault. In the second part we shall consider the evidence that exists on the extent of such allegations. In the third and final part we shall consider the efficacy of understanding false allegations as a product of different and competing interests in the production of the truth about what actually happened, and how an holistic appreciation of this truth production process, might further policy and practice. However, first of all it will be useful to consider what is actually meant by the term 'false allegation' in the context of rape and sexual assault.

\section{FALSE ALLEGATION: WHAT DOES THIS MEAN?}

Put at its simplest a 'false allegation' occurs when a complainant deliberately fabricates an event that they know actually did not occur (Norfolk 2011; Lisak et al. 2010). This would seem to be fairly obvious and straightforward. However, as commentators from a range of disciplinary perspectives have observed, for all practical purposes, there is in reality no consensus on what actually constitutes a 'false allegation' this simple definition notwithstanding. (See as an example of this debate the range of contributions to the journal Violence Against Women 2010 volume 16). Moreover, definitions of what constitutes a 'false allegation' are often conflated with motivations for making such allegations and/or indicators are used to measure it.

Norfolk (2011:228) offers one list of what is meant by 'false' in this context: retracted, malicious, not proceeded with, not proven, mistaken, and coerced. Here the conflation between individual motive and criminal justice practice is more than apparent. Rumney (2006) begins his discussion with the presumption that false allegation implies deliberate fabrication and from this develops a distinction between malicious and non-malicious allegations both of which may, in fact, result in being understood as false. Malicious allegations may include motives of revenge, financial gain, or covering up a 'night out' from a partner. Non-malicious allegations come in three forms; as a result of a medical condition, those that are technically false either in law (as, historically, in cases of marital rape), or those that are genuinely made but shown to be false (as a result of the influence of alcohol or drugs). Indeed, Engle and O'Donohue (2012) have proceeded to offer an analysis of eleven pathways into 'false allegations': lying, implied consent, false memories, intoxication, anti-social personality disorder, borderline personality disorder, histrionic personality disorder, delirium, psychotic disorders, dissociation, and intellectual disability. Moreover, alongside these issues, that focus attention on the problems presented by the complainant, it is important to add criminal justice practices.

Much feminist informed critique has put the spotlight on policing practices around rape and sexual assault in relation to false allegations. These practices appear to conflate the recording of crimes as 'unfounded' and the practice of 'no-criming' with false allegation (see for example Kelly 2010). Whilst in the U.K. there are strict guidelines governing the use of 'no-criming', the slippage in the application of these guidelines has been well documented. Indeed the Ministry of Justice (2010:35) reported that there was a 'misbelief that nocriming or an acquittal necessarily meant the allegation was false'; there was 'variation in interpretation of the no-crime category', and that there was 'general inconsistent police practice in no-criming'. These practices reflect a tendency to redefine women's voices (Kelly 2010) and point to the tensions that exist between the complainant's voice (wanting to be heard) and criminal justice imperatives (the search for corroborative evidence). When policing practices are overlaid with those of the Crown Prosecution Service (CPS), whose role as gatekeeper in the criminal justice system is pivotal in whether or not a case proceeds to court, these processes are compounded. Indeed, studies of the attrition rate of crimes of sexual violence in particular indicate that CPS involvement is a significant moment in this process (see inter alia Walby, Armstrong and Strid 2011). Whilst little empirical work has documented the day to day understandings of CPS professionals of false allegations per se, it is not too far-fetched to suggest that their overriding concern with the pursuit of cases 
'in the public interest' is likely to add another layer of complexity to what counts as 'false'.

In summary, the discussion so far points to three issues. First, it is evident that what counts as 'false' (and as we shall see, how it is counted) is highly contentious. Second, tensions exist between what the complainants' experiences might look like, how they remember them, what importance they assign to different aspects of that experience, and their motives for reporting their experiences; and the legal, cultural and professional context that frames the way in which criminal justice professionals respond to those experiences. Third, by implication, our attention is drawn to the tensions that potentially exist between everyday understandings of 'true' and 'false' and the criminal justice understandings of these terms for evidential purposes. As Jordan (2004:51) reminds us;

Whether or not an offence actually occurred is different from whether or not it can be proven to have occurred; for the victim of rape, the first concern is understandably more pressing, but because of their role in the prosecution process, it is the latter which is of primary importance to the police.

In the light of this discussion much remains to be said about how, the truth, the whole truth, and nothing but the truth, is produced. This issue will be returned to in part three of this paper. First it will be of value to consider what evidence exists as to the nature and extent of 'false' allegations. How big a problem is this, and if it is a problem, who for?

\section{FALSE ALLEGATION: NATURE AND EXTENT}

Concern about the nature and extent of false allegations has clearly fuelled debates for policy change, especially around the question of anonymity for defendants as well as complainants. Rumney (2006:129) and Norfolk (2011:229) both list a wide range of studies that have been conducted on the nature and extent of such allegations from the 1970s onwards. Taken together these studies suggest an alarming range in the extent of such allegations, from $2 \%$ to $90 \%$. Indeed, Saunders (2012:18) notes; 'the only thing we know with any certainty about the prevalence of false allegations of rape is that we do not know how prevalent they are'. Such a disparity clearly indicates that different studies use different definitions and different counting measures to achieve their estimates. No wonder that the Ministry of Justice (2010:34) report states that;

'Concrete evidence about the extent of false rape allegations is limited and confused, and what exists is based on perceptions of practitioners and research involving small samples'.

There is however, another issue at play here that is alluded to in the analysis offered by Rumney (2006). He suggests two trends in the empirical investigation of false allegations: one that starts from the assumption that women are very likely to make such claims, and the second, that emerged in the 1970s, that starts from the assumption that false allegations are no more likely in cases of rape than any other criminal cases. He goes on to suggest that the $2 \%$ figure, first quoted by Susan Brownmiller in 1975, has since become the consensus figure despite there being very little evidence to support it. Rumney's (2006) analysis of this notwithstanding, he is clearly pointing to the way in which the nature and extent of false allegations, in and of itself, has been debated more on the basis of belief rather than evidence. Indeed, the very different approaches to this topic that he highlights point to the depth with which views as to whether or not women 'cry wolf' are held and the profound effect these views have on the myths and the evidence that surround this question.

Rumney's (2006) precautionary advice notwithstanding, in a recent comparative study across 9 European countries Kelly (2010:1352) reports that rates of false allegation 'ranged between $1 \%$ and $9 \%$ with the majority at $6 \%$ '. From a point of view, whatever figure is arrived at, it is clear that the practices that produce such figures are hugely variable, and as Kelly (ibid) intimates, are a product of systemic tensions rather than individuals with a 'bad' attitude. On the basis of these findings Kelly calls for an international agreement on how false allegations should be counted and, in the light of this brief review of the data, it is not difficult to have some sympathy with this call. However the question arises as to what problem(s) such an agreement would solve? It would certainly result in a common framework for understanding the counting of false allegations as distinct from allegations that are no-crimed and/or unfounded that may in turn lead to a cultural change within criminal justice professionals in how they view each of these categories. Thus, the problem of false allegations would be better evidenced and thereby better understood by researchers, 
politicians, and policy makers. However, would this really tackle the tensions between what each of those party to the criminal justice process in dealing with cases of rape and sexual assault, from the complainant onwards, expect from their involvement in that process? Is there a different and/or better way to generate the requirements for evidence (the criminal justice search for the 'truth') without denying the complainant's desire to he heard (what s/he took to be what actually happened: their 'truth'?). Is it time, for all practical purposes, to leave the language of 'false allegation' behind us?

\section{THINKING DIFFERENTLY ABOUT THE SEARCH FOR TRUTH}

The perseverance and universality of the problem of 'truth' and why it may be time to think differently about it is illustrated in the mythological story of Cassandra. This story acknowledges the difficulty in convincing a male-dominated society to hear, understand, and heed a woman's message (Vagelatos 1995). The myth reflects reality, even in modem times, with often ageold customs and enduring laws written as if women were childlike frivolous beings not to be taken seriously or believed (Ronner 1997; see supra note 14:130). The assumption that children and women are of a similar ilk; interestingly defined as trusting yet, in the sexual sphere, not to be trusted, is key to understanding the concerns of this paper. It is evident that when reports of sexual assault fall outside of the widely accepted stockstories of rape (Wheatcroft, Wagstaff and Moran 2009) complainants/victims are still likely to be met with scepticism and mistrust by communities and professionals alike. How might it be possible to both challenge and change such perceptions?

Over twenty-five years ago, (Estrich 1987) made the distinction between 'real rape' and 'simple rape'. She suggests that real rape is the stereotypical situation involving one or several factors: a victim and an offender, who are unknown to one another, an interracial combination such as a white victim and a black stranger perpetrator(s), visible physical injury, and the use of force or a weapon. 'Simple rape' however is thought to contain characteristics that make them appear less serious, for example, they are typically perpetrated by someone the victim knows, do not result in injuries or employ weapons, and there may be no witnesses or accomplices. 'Real rapes' are more clear-cut in terms of lack of consent and are viewed as more serious and easier to prosecute. As such the 'real rape' stock-story unifies police and prosecution in decisions about priorities - particularly from a resource point of view. 'Simple rapes' are less likely therefore to proceed through the criminal justice system, and less likely to be taken seriously, despite constituting the majority of rape and sexual assault cases (Tjaden and Thoennses 2006). Moreover, complainants/victims themselves are subject to these same mistaken distinctions and as a result may doubt their own experience if it does not fit within the most widely accepted and represented definition of real rape/sexual assault. All of which, when taken together, adds to a systemic predisposition of 'falsehood', 'crying wolf', and/or telling lies being particularly associated to 'simple rapes', which nevertheless, constitute the majority of rape and sexual assault experiences, they remain the least likely to 'succeed' within the criminal justice system. The reasons as to why these patterns persist are arguably, multi-layered.

As noted earlier, women (and children) are by definition among the least powerful people in society perceptually making them peculiarly susceptible to disbelief in perception. Yarbrough and Bennett (2000) suggest that when powerful institutions' or individuals' claims are juxtaposed against those of less powerful or powerless institutions and individuals, the attachment of credibility to the powerful itself becomes indicia of power. This structural relationship of credibility becomes particularly potent when overlaid with the normative assumptions associated with heterosexual behaviour. Women may be considered, by men, to be sexually manipulative (Muehlenhard and Hollabaugh 1988) that can nurture in some men an entitlement to this (sexual) resource because that is what men have a right to (see also Scully 1990). Alternatively women can be viewed as cautious in their sexual relations and by definition want to be 'taken' (for an historical analysis of this see D'Cruze 2011).

The law, in both theory and practice needs to be situated within this wider social framing of power relationships and in doing so Naffine (2003) asks the question: who are law's persons? In an intriguing analysis of this question she argues that in the ever 'diminishing circle' of the person of law, from the most general (being human) to the more particular (being in possession of moral and legal responsibility), 'we exclude young children, and the adult incompetent. We also implicitly exclude wives who are unable to establish the complete autonomy of their will from that of their husband' (ibid:366). She goes on to argue that in terms of practice the most general form of laws' person (being human) is largely sidelined for that 
person who has moral and legal responsibility. This person is who she has termed elsewhere as 'the rational man of law' (Naffine 1990). This gradual curtailment of law's person has real consequences in terms of what is understood to be reasonable course of action in particular circumstances. Set against this backcloth the findings reported by Saunders (2012) on the persistence of beliefs surrounding rape cases on the part of practitioners need to be understood.

Judges, for example, do try to be impartial and derive decisions purely from the law and evidence. However, research suggests that, what are referred to as, 'anchored narratives' can be influential (Wagenaar, vanKoppen and Crombag 1993). These anchors can be described as common sense rules generally expected to be true: unquestioned assumptions concerning people, behaviour, and ideas. They reflect presumptions about the person of law: the benchmark against what and who counts as 'reasonable' under particular circumstances. Importantly, these assumptions can reflect stereotypes that attach narratives to commonly held perceptions (i.e. 'once a thief always a thief' or 'drug abusers are always thieves'). Such narratives may be implicitly embedded within legal decision making (rather than explicitly) but their significance in relation to sexual assault cannot be denied. For example, Beichner and Spohn (2012:3) report:

'Our results reveal that although charging decisions in stranger cases are largely determined by legally relevant factors, these decisions in non-stranger cases are affected by several legally irrelevant victim characteristics: whether the victim had a prior criminal record, whether the victim had been drinking alcohol prior to the assault, and whether the victim invited the suspect to her residence. Further analysis, however, revealed that only the victim's prior record had a differential effect on charging decisions in cases involving strangers and non-strangers and in aggravated and simple rape cases. Our results suggest that the focal concerns that guide prosecutors' charging decisions incorporate specific victim behaviors and background characteristics.'

These findings point to not only the continued efficacy of the real rape/simple rape dichotomy held by practitioners but also the power that anchored narratives (in this example about the variables that count as evidence for real rape/simple rape) in fuelling decision making. Thus for our purposes this affords one way of understanding how aspects of a complaint are likely to be dealt with as credible or otherwise. Worryingly, anchors do not need to be correct or even held in common but their combined effect is no less telling (Wheatcroft, 2012). Thus, as Kelly also notes, 'legacies remain sedimented into institutional cultures and practices, creating a risk of over-identification of false allegations by police and prosecutors' (2010:1345).

In summary, there is obvious public interest in determining the credibility of sexual assault. Historically however the law in general, sexual offence laws in particular, and public stereotypes surrounding both women (Jordan 2004) and children (Quinn 1988; Yates and Musty 1988) have led to the perception of these groups of complainants as not to be trusted and to be observed largely as storytellers. These cultural stereotypes inform more than criminal justice practice important as this is. For example, the percentage of rapes reported to police that result in a conviction is notoriously small across many countries, including England and Wales (Walker, Kershaw and Nicholas 2006), South Africa (South African Law Commission, n.d.) and the United States (Sinclair and Bourne 1998). These small percentages might partially be explained by pervasive myths and stereotypes; those 'prejudicial, stereotyped or false beliefs about rape, rape victims, and rapists' (Burt 1980:217) that are widely held in society and affect decision making at each stage of the criminal justice process. At their most acute, according to Ms Saunders, chief prosecutor for London, 'juries acquitting suspects is now the largest reason for failures in rape prosecutions'. She also said 'society should challenge myths including commonly held beliefs that rape was carried out by strangers in dark alleys and that women who were drunk were asking to be attacked' (Davenport 2012). Moreover, myths are not contained to uninvolved observers but can also be present in the alleged victim. For example, Weiss (2009) found that one in five victims in the United States excused or justified their offender's behaviour, often drawing on myths and stereotypes as indicated here.

So, anchored narratives around what and who is, and is not, to be believed have an impact in a myriad of ways. However, what if we started in a different place? What if we accepted the belief (i.e., what we term here 'interactional belief'), that women (and children), on the 
whole, do not lie? What would this imply for anchored narratives of practitioners so well highlighted by Saunders (2010) and where would that take the debate on 'false allegations'? In making a case for this starting point there may be something to be learned, for criminal justice practice, from recent initiatives designed to address children as victims of sexual abuse.

\section{OUT OF THE MOUTHS OF BABES .......?}

There has been a parallel debate in relation to false allegation with children as victims of sexual abuse (i.e. not believed, telling stories/lying, allege as revenge on another), as with women in cases of rape. Here too there have been deeply held views that children lie/tell stories. However, it has been suggested (Davies 1992) that children as young as six years of age can provide as accurate information as adults if obtained early. Further to this, the extent of false allegations has also been subject to scrutiny with Jones and McGraw (1987) suggesting that allegations from children stand at circa $1 \%$. Kelly (2010) similarly notes that false allegations are no higher for rape where adults are concerned than for other crimes (see also Gilmore and Pittman 1993). The same is the case for children. Yet in both kinds of cases (child sexual abuse and adult cases of rape/sexual assault) the practitioner role in the investigation of crime is not only core (ACPO 2004) it is crucial in contributing to the value of the information provided by complainants, witnesses, and victims of crime (Kebbell and Milne 1998). In 2011, the U.K. released a revised version of Achieving Best Evidence in Criminal Proceedings: Guidance on interviewing victims and witnesses, and guidance on using special measures (ABE 2011 - originally drafted in 2002 as Guidance for Vulnerable or Intimidated Witnesses, Including Children). Of course, adult female rape complainants are too considered vulnerable within this framework; though the rhetoric for female rape complainants continues to be myth-laden with consequent echoes of revictimization (Wheatcroft, et al. 2009). In approaching interactions with children research indicates advantages of the rapport phase. For example, Collins and Eaton (2013) have recognised the necessity of rapport in highlighting that interpersonal styles show improvements in children's communication during interviews. Thus, the practitioner implications for responding to children may well have important, even crucial, parallels facilitating a more holistic way of thinking about how to respond to adult complainants of rape and sexual assault. This stance is notably supported by psychological evidence.
As is well established, the interaction between victims and investigators can strengthen or weaken an investigation and thereby has a powerful role in whether the case is ultimately prosecuted or not. Traditionally, police officers have tended to dominate interviews of rape complainants (Kebbell and Westera, 2011). However, rapport, for example, allows opportunity to; a) set conditions which optimise focus, communication, memory, and motivation, and b) establish a trusting relationship between complainant and interviewer (Saywitz, Camparo and Romanoff 2010). Such a concept is not a new idea, and some time ago, Warren, Woodall, Hunt and Perry (1996) talked of this process as 'warming up'. Indeed, Patterson (2012) reported that supportive detectives who developed rapport with victims, helped produce stronger statements, build a stronger case, and prevent additional psychological distress to the victim. Researchers also agree that the atmosphere created by interviewer manner can either facilitate (e.g. increase trust) or hinder (e.g. intimidate; closing pathways to trust development) the interview process (Saywitz and Camparo 1998). Moreover, authoritative style can be equally intimidating and affect reliability by increasing compliance to misleading information (Leichtman and Ceci 1995). This aspect is particularly salient in contexts where powerful-powerless meet and where stereotypical assumptions of case detail implicitly lead.

Usefully then, a supportive interviewer manner may well decrease fears of perceived authority status (Carter, Bottoms and Levine 1996). In a study on the impact of interviews on rape survivor's reduction of hierarchy accomplished through mutual dialogue resulted in greater levels of comfort and disclosure (Campbell et al. 2010). Thus, a rapport development technique (i.e. commencement or maintenance of a trusting relationship perhaps through discussion of neutral topics, process, and/or interpersonal approach) can be an especially effective tool to encourage truthful disclosure. Likewise, the process of rapport may also influence and produce longer narratives which have been shown to yield more accurate credibility assessment of abuse allegations (Hershkowitz, Fisher, Lamb and Horowitz 2007). In addition, most individuals have limited knowledge of the legal system which can contribute to heightened anxiety during investigative interviews. Spohn and Tellis (2012) note that victim complainants feared the criminal justice system would cause them shame, embarrassment, and ultimately humiliation. In this regard, evidence shows that high levels of anxiety and stress hinder cognitive function, 
diverts attention and reduces motivation vital for accurate memory retrieval (ABE 2011). On this basis the context of false allegation is likely to eliminate rapport harnessed between the victim and investigator (McDowell and Hibler 1993). Given this, the authors contend that it is difficult to engage in any meaningful rapport and create the appropriate atmosphere of trusted and trusting within the context of disbelief in which myth and stereotype flourish. Thus a benchmark is set premised firmly on interactional belief rather than disbelief for the successful resolution of a case. Moreover, in order to move this process from one that is rooted in disbelief to one rooted in belief it is important to appreciate the truth generating process as a holistic one in which there are competing perspectives and interests.

For the rape complainant there exist three potential interfaced perspectives that are relevant to understanding how 'what happened' might be made sense of: the experiential, the practice, and the legal. Each of these perspectives has the potential to structure the psychological expectation of belief/disbelief on a continuum and when perspectives are together, practitioner and legal roles sit inelegantly with experiential perspectives. It is within the spaces between these differently competing perspectives referred to from here on in as anchored narratives that the spectre of false allegation takes shape.

Such anchored narratives are most apparent in police practices though not exclusively so police interviewers may begin their search for the truth by unwittingly examining any available evidence to refute the complainant's claim, for example by asking questions such as what were you wearing, was it late at night, did you know the person, etc. In their terms this counts as 'testing the evidence'. In asking questions such as these police interviewers are taking statements in which it is necessarily incumbent upon them to provide evidence of believability. So, if the offence was theft the interviewer would likely ask what happened, when, what was taken, how was it taken. The line of question in and of itself reflecting an anchored narrative that works for them in making sense of what has happened that enables them to make a believable case for those in the next stage of the prosecution process. Interestingly, in our example of theft, interviewers are unlikely to ask, did you leave the doors and windows open, was the object freely available, on show, etc., thereby suggesting the invitation of theft. In 'testing the evidence' in cases of sexual assault, however, the benchmark of believability and it associated anchored narratives results in an inverted process of evidence seeking. Thus, complainants are asked; have you been drinking, what were you wearing, did you invite him in for coffee, and so on. In this way it becomes more than evidence that the complainants desire to report what happened produces narratives that conflict with the practitioner's desire to present a case that is both believable and defensible.

In real terms, this means that individuals, in this case police officers, have a tendency to seek an explanation for the allegation in and of itself and thus to explore how does this narrative compare with the stereotype template, how might it be invalidated, rather than take the allegation to be the basis of what did happen. This is most acute at the stage of police intervention and where the CPS demand particular evidence that would result in an overwhelmingly strong percentage of likely conviction: arguably the benchmark of believability not necessarily a reflection of what actually happened. This is an important point from a cognitive vantage point. If allegations are inflated or conflated, and thereby inaccurately portrayed, then the perception of those practitioners at the interface between law and complainant can simply enable a perseverant picture that most claims of rape are false.

A particular point of contention to note is that of the need for consistency in evidence. Research has demonstrated that when mock-jurors hear inconsistent recall testimony they perceive eyewitnesses to be less accurate and credible (Berman, Narby and Cutler 1995; Brewer et al. 1999). Interestingly though, a study conducted by Granhag and Stromwall (2005) found the most frequent cue to adult detection of child deception was consistency of the child's statement (see also Quas et al. 2007). Problematically, inconsistency could operate to lower perceived credibility by lowering perceived confidence and thereby believability (Wheatcroft, Wagstaff and Kebbell 2004). Thus, while law marks consistency as a credible indicator, where a consistent report seems to be more accurate or truthful (Berman et al. 1995; Brewer, et al. 1999), it is nevertheless at odds with research of children. Inconsistency has been shown as demonstrating a higher degree of accuracy in testimony (i.e. lack of rehearsal of testimony, a truer account of real memory recall, lack of motivation to manipulate, and so on). The same can also apply to adult testimony in which inconsistency, differential recall and so on, are common features of eyewitnesses'/complainants' testimony. Indeed, this is the nature of recall in everyday life. Therefore, from a psychological 
perspective, inconsistencies and inaccuracies in recall are to some extent to be expected (in adults and children) in reporting experiences of rape and/or sexual assault. However the value of such testimony is doubly underpinned by the premise of disbelief.

Thus we suggest the term false allegation is a common sense simplification of a complex legal and social arena. Its reliance on myth and stereotype seem evident and these appear to have some sense of pluralistic influence; i.e. people mistake each other's beliefs by misinterpreting behaviour and then use that as evidence for what must be the truth. This represents the relevant social-cognition for rape, the interpretation of victim behaviour, and judges' and jurors' understandings of rape complainants and defendants. For the interpreter in a complex web of competing perspectives it is psychologically safe if the responsibility can be diffused; it becomes a place where 'it cannot possibly happen to me'; 'I don't have the same characteristics as this person' (complainant victim). However, the ways in which common sense oversimplifies dangerously underestimates the power of social situations in police roles, in interviews, in allegation contexts, and in judicial process. The result is perseverant thoughts, behaviours and outcomes (i.e. we keep thinking and doing the same things and are surprised when we continue to get the same results (de Shazer 1988). We have opportunity to learn from previous mistakes and fail to do so, yet all of which seems to have been somewhat better achieved with children (see Holliday and Marche 2013). From this perspective it is simple to appreciate how practitioner police (also subject to cognitive shortcuts), in their transactions with the complainant, can blame and/or misconstrue rape complainant and/or victims and label or report evidence as 'false allegation'. There exist too many spaces in which 'false allegation' can surface.

What emerges from the process of reporting through to prosecuting and ultimately conviction, is that there are a number of constituent parts that make up the whole of 'false-allegation'. The term represents a rigid structure: a crude, shorthand concept in which significant attribution errors are at work. The ascriptions noted make individuals feel good, enable some sensemaking of what is being presented to them, and assists to resolve inner conflicts that surround the event. However, such attributions are guided by stereotypical beliefs and assumptions; myths. Women 'cry wolf'. It is simply cognitively easier to work from and for a police officer, judge or juror, since 'it cannot possibly happen to me - I do not have the same characteristics as this person' anything outside of the safety zone provides the conditions for slippage into another 'false allegation'. Yet, as we have suggested here, many of these issues have largely been tackled or addressed where children are concerned, prior to trial (Holliday and March 2013). A key aspect to their avoidance has been to begin any investigation of rape or sexual assault from the premise of interactional belief.

\section{CONCLUSION}

It is increasingly obvious that false-allegation as a term is confused, lacks clarity, and represents a dichotomous variable applied in non-dichotomous situations. Importantly, its relative lack of success in practice makes it meaningless for policy makers and practitioners. Lessons have to be learned from the treatment of children in sexual offence cases and their efficacy to the treatment of women in cases of rape needs to be considered.

In order to achieve this, maybe there is mileage in embracing a case formulation model not a pathologising model for all criminal justice practitioners, particularly in cases of rape and sexual assault. A case formulation model is one that premises belief as its opening gambit. This method would aim to disprove the 'believability hypothesis' model rather than using disbelief as the general framework from the outset. Hart, Sturmey, Logan and McMurran define formulation as 'the process or product of gathering and integrating diverse information to develop a concise account' (2011:118). As noted in this paper, approaches to child complainants have moved solidly in this direction. Despite limited evidence bases, formulation allows for more than mere description, diagnosis, or statistic; it facilitates explanation, identifies origins of the problems and addresses individual need; thus minimising the potential for the aggravating influence of myth and stereotype.

Finally, by leaving the accusatory language of false allegation behind, complainants, practitioners and judicial parties may experience more successful pathways to truth. It seems that the debate may now reflect a distraction from central issues of approach to the false allegation process. Moving in this direction will not be easy, since by implication it would mean making in-roads into the dominant, for all practical purposes, concept of law's person being the reasonable man of law. However as Naffine (2003:367) implies understanding the person of law as a human being in its most general sense has an important capacity: 'to stand for all'. By means of the lessons learned from 
practice with children in sexual assault cases the myth 'the only good woman is a silent woman' (Jordan 2011:278) can begin to be dispelled: but only if interpersonal practices, one of which may be interactional belief, that derive from the law means the law can stand for us all.

\section{REFERENCES}

Achieving Best Evidence in Criminal Proceedings: Guidance on interviewing victims and witnesses, and guidance on using special measures, ABE 2011. London: Home Office.

Achieving Best Evidence in Criminal Proceedings: Guidance for Vulnerable or Intimidated Witnesses, Including Children, ABE 2002. London: Home Office.

Adler, Z. 1987. Rape on Trial. London: Routledge, Kegan and Paul.

Association of Chief Police Officers. 2004. Management of Volume Crime. Bramshill, National Centre for Policing Excellence.

Belknap, J. 2010. "Rape: Too Hard to Report and Too Easy to Discredit Victims" Violence Against Women, 16(12):13351344. http://dx.doi.org/10.1177/1077801210387749

Beichner, D. and Spohn, C. 2012. Modeling the effects of victim behavior and moral character on prosecutors' charging decisions in sexual assault cases. Violence and Victims, 27(1):3-24. http://dx.doi.org/10.1891/0886-6708.27.1.3

Berman, G.L., Narby, D.J. and Cutler, B.L. 1995. Effects of inconsistent statements on mock jurors' evaluations of the eyewitness, perceptions of defendant culpability and verdicts. Law and Human Behavior, 19:79-88. http://dx.doi.org/10.1007/BF01499074

Brewer, N., Potter, R., Fisher, R.P., Bond, N. and Luszcz, M.A. 1999. Beliefs and data on the relationship between consistency and accuracy of eyewitness testimony. Applied Cognitive Psychology, 13(4):297-313. http://dx.doi.org/10.1002/(SICI)10990720(199908)13:4<297::AID-ACP578>3.0.CO;2-S

Brown, J. and Horvath, M. 2009. "Do you believe her? Is it real rape?" Pp. 325-343 in Rape; Challenging Contemporary Thinking, edited by M. Horvath and J. Brown. London: Routledge-Willan

Brownmiller, S. 1975. Against our Will: Men, Women and Rape. London: Secker and Warburg.

Burt, M.R. 1980. "Cultural myths and supports for rape." Journal of Personality and Social Psychology, 38:217-230. http://dx.doi.org/10.1037/0022-3514.38.2.217

Campbell, R., Adams, A. E., Wasco, S. M., Ahrens, C. E. and Sefl, T. 2010. "What has it been like for you to talk with me today?: The impact of participating in interview research on rape survivors." Violence Against Women, 16(1):60-83. http://dx.doi.org/10.1177/1077801209353576

Carter, C., Bottoms, B. and Levine, M. 1996. "Linguistic and socioemotional influences on the accuracy of children's reports." Law and Human Behavior, 20:335-358. http://dx.doi.org/10.1007/BF01499027

Davenport, J. 2012. "Top prosecutor points finger at Johnny Depp over rape myths that let suspects go free." Crime correspondent, $30^{\text {th }}$ January 2012. Accessed $28^{\text {th }}$ August at $\mathrm{http}: / /$ www.standard.co.uk/news/top-prosecutor-points-fingerat-johnny-depp-over-rape-myths-that-let-suspects-go-free7312932.html

Davies, G.M. 1992. "Influencing public policy on eye-witnessing: Problems and possibilities." In Psychology and Law: International Perspectives edited by F. Losel, D. Bender and T. Bliesner. Berlin: De Gruyter http://dx.doi.org/10.1515/9783110879773.265
D'Cruze, S. 2011. "Sexual violence in history: a contemporary heritage?" Pp. 23-52 in Handbook of Sexual Violence edited by J. Brown and S. Walklate. London: Routledge.

de Shazer, S. 1988. Clues: Investigating solutions in brief therapy. New York, NY: WW Norton \& Company.

Collins, K. and Eaton, A. 2013. "Communicative scaffolding in the rapport phase of child investigative interviews." Paper presented to the $6^{\text {th }}$ Annual Conference of the International Investigative Interviewing Research Group, Maastricht University, The Netherlands, $3^{\text {rd }}-5^{\text {th }}$ July 2013.

Engle, J. and O'Donohue, W. 2012. "Pathways to False Allegations of Sexual Assault." Journal of Forensic Psychology Practice, 12(2):97-123. http://dx.doi.org/10.1080/15228932.2012.650071

Estrich, S. 1987. Real Rape. Harvard University Press

Gavey, V. and Gow, E. 2001. "'Cry Wolf', Cried the Wolf: Constructing the Issue of False Rape Allegations in New Zealand Media Texts." Feminism \& Psychology, 11(30):34160. http://dx.doi.org/10.1177/0959353501011003006

Granhag, P.A., and Stromwall, L.A. 2005. "Children's repeated lies and truths: effects on adults' judgments and reality monitoring scores." Psychiatry, Psychology and Law, 12(2),345-356. http://dx.doi.org/10.1375/pplt.12.2.345

Hart, S., Sturmey, P., Logan, C. and McMurran, M. 2011. "Forensic case formulation." International Journal of Forensic Mental Health, 10:118-126. http://dx.doi.org/10.1080/14999013.2011.577137

Hershkowitz, I., Fisher, S., Lamb, M.E. and Horowitz, D. 2007. "Improving credibility assessment in child sexual abuse allegations." Child Abuse and Neglect, 31:99-110. http://dx.doi.org/10.1016/j.chiabu.2006.09.005

Holliday, R.E. and March, T.A. 2013. Child Forensic Psychology. London: Palgrave.

Jordan, J. 2004. The word of a woman: Police, rape and belief. London: Palgrave. http://dx.doi.org/10.1057/9780230511057

Jordan, J. 2008. Serial Survivors: Women's Narratives of Surviving Rape. Sydney: The Federation Press.

Jordan, J. 2011. Silencing rape, silencing women. Pp. 253-287 in Handbook on Sexual Violence edited by J. Brown and S. Walklate. London: Routledge.

Kebbell, M.R. and Milne, R. 1998. "Police officers' perceptions of eyewitness performance in forensic investigations." Journal of Social Psychology, 138(3):323-330. http://dx.doi.org/10.1080/00224549809600384

Kebbell, M.R. and Westera, N.J. 2011. "Promoting pre-recorded complainant evidence in rape trials: Psychological and practice perspectives." Criminal Law Journal, 35:376-385.

Kelly, L. 2010. "The (In)credible Words of Women: False Allegations in European Rape Research." Violence Against Women, 16(12):1345-1355. http://dx.doi.org/10.1177/1077801210387748

Leichtman, M.D. and Ceci, S.J. 1995. "The effects of stereotypes and suggestion on preschoolers' reports." Developmental Psychology, 31:568-578. http://dx.doi.org/10.1037/0012-1649.31.4.568

Lisak, D., Gardinier, I., Nicksa, S. and Cote, A. 2010. "False Allegations of Sexual Assault: An Analysis of Ten Years of Reported Cases." Violence Against Women 16(12):13181334. http://dx.doi.org/10.1177/1077801210387747

McDowell, C.P. and Hibler, N.S. 1993. "False allegations." Pp. 275299 in Practical aspects of rape investigation: A multidisciplinary approach edited by R.R. Hazelwood \& A.W. Burgess. Boca Raton, FL: CRC Press. 
Ministry of Justice 2010. Providing anonymity to those accused of rape: An assessment of evidence. Ministry of Justice Research Series 20/10. London: Ministry of Justice.

Muehlenhard, C.L. and Hollabaugh, L.C. 1988. "Do women sometimes say no when they mean yes? The prevalence and correlates of women's token resistance to sex." Journal of Personality and Social Psychology, 54(5):872-879. http://dx.doi.org/10.1037/0022-3514.54.5.872

Naffine, N. 1990. Law and the Sexes. London: Allen and Unwin

Naffine, N. 2003. "Who are Law's Persons? From Cheshire cats to responsible subjects." Modern Law Review, 66(3):346-67. http://dx.doi.org/10.1111/1468-2230.6603002

Norfolk, G.A. 2011. "Leda and the swan - And other Myths about Rape." Journal of Forensic and Legal Medicine, 15:235-32.

Patterson, D. 2012 online first 11 January. "The impact of Detectives' questioning techniques on rape victims' disclosure." Violence Against Women. http://dx.doi.org/10.1177/1077801211434725

Quas, J.A., Davis, E.L., Goodman, E.S. and Myers, J.E.B. 2007. "Repeated questions, deception, and children's true and false reports of body touch." Child Maltreatment, 12(1):60-67. http://dx.doi.org/10.1177/1077559506296141

Quinn, K. 1988. "The credibility of children's allegations of sexual abuse." Behavioral Science and Law, 6:181-99. http://dx.doi.org/10.1002/bsl.2370060204

Ronner, A.D. 1997 supra note 14. "The Cassandra Curse: The Stereotype of the Female Liar Resurfaces in Jones v. Clinton." UC Davis Law Review, 31:123-191. Explains that the myth of the female liar in many sexual harassment cases is a strong obstacle for plaintiffs to overcome.

Rumney, P. 2006. "False Allegations in Rape." Cambridge Law Journal, 65(1): March, 128-158. http://dx.doi.org/10.1017/S0008197306007069

Saunders, C.L. 2012 online first 9 August. "The truth, the half-truth, and nothing like the truth: Reconceptualizing false allegations of rape." British Journal of Criminology. http://dx.doi.org/10.1093/bjc/azs036

Saywitz, K., and Camparo, L. 1998. "Interviewing child witnesses: A developmental perspective." Child Abuse \& Neglect, 22(8):825-843.

http://dx.doi.org/10.1016/S0145-2134(98)00054-4

Saywitz, K., Camparo, L.B. and Romanoff, A. 2010. "Interviewing children in custody cases: Implications of research and policy for practice." Behavioral Sciences and the Law, 28:542-562.

Scully, D. 1990. Understanding Sexual Violence. London: Unwin Hyman.

Sinclair, H.C. and Bourne, L.E. 1998. "Cycle of blame or just world: Effects of legal verdicts on gender patterns in rape-myth acceptance and victim empathy." Psychology of Women Quarterly, 22:575-588. http://dx.doi.org/10.1111/j.1471-6402.1998.tb00178.x

South African Law Commission (n.d.). Conviction rates and other outcomes of crimes reported in eight South African police areas: Research Paper 18. Pretoria, South Africa: South African Law Commission.

Spohn, C. and Tellis, K. 2012. "The Criminal Justice System's Response to Sexual Violence." Violence Against Women, 18(2):169-192.

http://dx.doi.org/10.1177/1077801212440020
Stanko, E.A. and Williams, E. 2009. "Reviewing rape and rape allegations in London: what are the vulnerabilities of the victims who report to the police?" Pp. 207-229 in Rape; Challenging Contemporary Thinking edited by M. Horwath and J. Brown. London: Routledge-Willan.

Stern, V. 2010. The Stern Review. London: Government Equalities Office.

Tjaden, P. and Thoennes, N. 2006. Extent, Nature, and Consequences of Rape Victimization: Findings From the National Violence Against Women Survey. Special Report. Washington, D.C.: National Institute of Justice and the Centers for Disease Control and Prevention.

Vagelatos, J. 1995 supra note 5. "Heeding Cassandra: The Neutered Mother, the Sexual Family, and Other Twentieth Century Tragedies." Journal of Gender and Law, 5:127-141. Critiquing The Neutered Mother, the Sexual Family and Other Twentieth Century Tragedies by Martha Albertson Fineman concluding the author provides a new feminist legal viewpoint that will impact the debate about single mothers and welfare).

Wagenaar, W.A., vanKoppen, P.J., and Crombag, H.F.M. 1993. Anchored narratives: The psychology of criminal evidence. Hemel Hempstead: Harvester Wheatsheaf.

Walby, S. Armstrong, J. and Strid, S. 2011. "Developing measures of multiple forms of sexual violence and their contested treatment in the criminal justice system." Pp. in Handbook on Sexual Violence. London: Routledge.

Walker, A., Kershaw, C. and Nicholas, S. 2006. Crime in England and Wales 2005/6. London: Home Office.

Warren, A.R., Woodall, C.E., Hunt, J.S. and Perry, N.W. 1996. "It sounds good in theory, but ....': Do investigative interviewers follow guidelines based on memory research?" Child Maltreatment, 1:231-245.

http://dx.doi.org/10.1177/1077559596001003006

Weiss, K.G. 2009. 'Boys will be boys' and other gendered accounts: An exploration of victims' excuses and justifications for unwanted sexual contact and coercion." Violence Against Women, 15:810-834.

http://dx.doi.org/10.1177/1077801209333611

Wheatcroft, J.M. 2012. “Judicial Processes”. Pp. 229-246 in Forensic Psychology: Crime, Justice, Law, Interventions, $2^{\text {nd }}$ Edn edited by G. Davies, \& A. Beech, John Wiley \& Sons: Chichester.

Wheatcroft, Wagstaff and Kebbell, M.R. 2004. "The influence of courtroom questioning style on actual and perceived eyewitness confidence and accuracy." Legal \& Criminological Psychology, 9:83-101. http://dx.doi.org/10.1348/135532504322776870

Wheatcroft, J.M., Wagstaff, G.F. and Moran, A. 2009. "Re-Victimising the victim? How rape victims experience the UK legal system." Victims and Offenders 4(3):265-284. http://dx.doi.org/10.1080/15564880903048529

Yarbrough, M. and Bennett, C. (2000), "Cassandra and the "Sistahs": The peculiar treatment of African American women in the myth of women as liars." Gender, Race and Justice, 3:625658.

Yates, A. and Musty, M. 1988. "Preschool children's erroneous allegations of sexual molestation." American Journal of Psychiatry, 145:989-92.

Received on 19-06-2014

Accepted on 14-07-2014

Published on 27-08-2014

DOI: http://dx.doi.org/10.6000/1929-4409.2014.03.20

(c) 2014 Wheatcroft and Walklate; Licensee Lifescience Global.

This is an open access article licensed under the terms of the Creative Commons Attribution Non-Commercial License (http://creativecommons.org/licenses/by-nc/3.0/) which permits unrestricted, non-commercial use, distribution and reproduction in any medium, provided the work is properly cited. 